\title{
Predicative Clauses in Today Persian - A Typological Analysis
}

\author{
Pooneh Mostafavi ${ }^{1}$ \\ ${ }^{1}$ Research Institute of Cultural Heritage and Tourism of Islamic republic of Iran, Tehran, Iran \\ Correspondence: Pooneh Mostafavi, Assistant Professor in General Linguistics, Research Center of linguistics, \\ Inscriptions, and Texts, Research Institute to Iranian Cultural Heritage and Tourism of Islamic republic of Iran, \\ Tehran, Iran. Tel: 98-21-66-736-5867. E-mail: mostafavi1972@gmail.com
}

Received: December 24, 2014 Accepted: February 23, 2015 Online Published: May 15, 2015

doi:10.5539/ass.v11n15p104

URL: http://dx.doi.org/10.5539/ass.v11n15p104

\begin{abstract}
Predicative clauses in world languages encode differently. There are typological researches on this subject in other languages but none of them is on Persian. Stassen in his typological studies shows that the world languages have yielded two strategies for encoding predicative clauses. Copulative and locative/existential constructions are considered as predicative clauses. The strategies which Stassen claims are 'share' and 'split' strategies. According to Stassen some languages employ one of them and some employ both strategies. He shows in his studies, the language type can be determined by examining the said strategies in them. Using normal data, the present study examines two strategies for today Persian in order to determine its language type. The findings of the present study show that Persian could be categorized in both language types as both strategies are employed by it.
\end{abstract}

Keywords: predicative clauses, copulative construction, locative/existential construction, share strategy, split strategy

\section{Introduction}

Copulative constructions are those having copular verbs and the copula links the subject NP to NP, AP, AdvP, and PP. Of these sentences those having a PP as their complement and the PP head is a locative preposition are called locative sentences. Other sentences having copular verbs are called existential sentences. According to Stassen in his 1997, 2005, and 2009 typological studies, the encoding strategies for copulative and locative/existential constructions in the world languages are not the same and are divided into share and split, each with its subdivisions, hence two language types. Since the present study is of a functional-typological nature, requiring a corpus-based approach, a language corpus consisting of 200 normal sentences of Persian was utilized. The objective is to examine the ways copulative and locative/existential constructions are encoded in today Persian in order to determine its language type by the data provided by PLDB.

\section{Review of Previous Scholarship}

The section reviews the studies carried out by the Iranian and non-Iranian grammarians and linguists on the copular verbs, copulative clauses, and locative/existential clauses. The scholars are divided into Iranian and non-Iranian for ease of reference. It is noteworthy that some grammarians have not mentioned the copular verbs, copulative clauses, and locative/existential clauses explicitly, Haakemi (1960), Shafa'ee (1984), Baateni (1993), and Rassekh-Mahand (2009) just to name a few. Lambton (1984 [1953]) has not enter into the matter in her Persian grammar and Huddleston and Pullum studying English grammar, have mentioned just the kinds of the linking verb 'to be' with a few examples without further description, instead of copulative and locative/existential constructions.

\subsection{Iranian Scholars}

Some Iranian scholars have studied Persian predicative constructions. Among them there are traditional grammarians- those who wrote Persian grammar according to basic principles of Arabic not according to linguistic frameworks- and linguists. But none of the said scholars have studied this kind of construction based on typological frameworks. The next two subtitles have dealt with their viewpoints separately.

\subsubsection{Traditional Grammarians}

According to traditional grammarians, Persian sentences have been divided into two categories: "Aam" (copulative), and "Tam" (non-copulative). "Aam" sentences are those having a copula and attribute a feature or 
state (Mosnad) (predicate) to the subject of the sentence. /budæn/ (to be) and /šodæn/ (to become) are among the copulas./hæstæn/ (to exist) is another copula. /budæn/ is sometimes cliticized and joins the host( predicator Mosnad). Some scholars prefer to use the term 'Mokhaffaf' (abbreviated form) instead of cliticized (Mashkoor, 1976; Ravayee, 1991; Nobahar, 1993; Ghareeb et al, 2006 [1994]; Sadeghi and Arzhang, 1979). The copula is just a linking element and has no full meaning; if it has a meaning such as 'to exist' it cannot be considered a copula anymore (Mashkoor, 1976; Ahmadi-Geevi and Anvari, 2008 [1988]; Shari'at, 1988). Some like Nobahar (ibid:1993) suggests that adverbs may be added to the copulative construction as adjuncts which are not complements, yet in some instances their omission changes the sentence meaning dramatically.

The verbs /budæn/ and /hæstæn/ are both copular: /budæn/ emphasizes the 'Mosnad' (predicate) but /hæstæn/ puts more emphasis on the linkage (Khanlari, 2007 [1972]; Mashkoor, 1976).

Still, other traditional grammars such as Ash'ari (1994) have just given the present tense inflected forms of /budæn/ right similar to /hæstæn/.

Traditional grammarians have just studied the verbs in predicative constructions based on their meanings. They have not dealt with the construction according to its structural behaviors.

\subsubsection{Linguists}

On the contrary to traditional grammarians, Iranian linguists have studied predicative construction not just based on meaning but on different linguistic approaches. According to them Persian verbs can be categorized in terms of their complements into several classes. The copula can be found in the sentences having VP composed of either NP, AP, PP, or AdvP accompanying a verb. The four categories are called 'Mosnad' (predicate) or 'Motammem' (complement). Semantically speaking, the copula links the subject to the complement - no linkage if negative. The sentences with locative preposition are regarded as locative and if an adverb of place is the 'Mosnad'(predicate), then the verb after which is not a copula but signifies 'to be existent' (Meshkaatoddini, 1994; Gholamalizadeh, 1995; Meshkaatoddini, 2005; Vahidian-Kamyar et al., 2007). The sentences having the copula are called "Esnaadi" (copulative). In generative grammar, the complement and the copula altogether consists the central verb, but according to the dependency grammar, the copula is considered as the central verb and also all the copulas have a valency consisted of a subject and a 'Mosnad'(predicate) (Tabibzadeh, 2011). The verb /budæn/ in today Persian is used in three forms as a copula: as cliticized form, as /hæstæn/ with agreement, and as /bašidæn/ with agreement. The past tense form of the copula is /budæn/. The copula is obligatory in the sentences with N, A, or Adv complements. As a rule in Persian, there is no copulative construction without an obvious copula (Mahootian, 2008). The verb /hæstæn/ can be used as 'to be existent' (ibid: 217). The verbs $/$ Rst/, /hæst/, and /mibašæd/ are copula and main verbs for they are quire the complements. In this case they are synonymous with 'to be existent' (Farshidvard, 2005). Such nominal sentences as /sigarkešidænmæmnu?/ (No smoking) are the very copulative constructions having their copula omitted. In the above case, it can be rewritten by adding the copula /Ræst/ (Tabibzadeh, 2011; Vahidian-Kamyar, 2007).

Being the most neutral copula, the verb/budæn/ is the main copula with no semantic content beyond the linkage. The main reason for the omission of the morpheme /hæmi/ or /mi/ in the collocation with the verb /budæn/ as a static verb as well as its grammaticalization in Persian may be attributed to the progressiveness and continuity in itself. /budæn/ as a main verb behaves as the copula, being a one-place intransitive verb and meaning to be existent'. Yet, /budæn/ as a copula is a two-place verb with both internal and external arguments. Both verbs are resistant to the progressive construction. The third function of /budæn/ is as an auxiliary in the peripheral constructions (Mofidi, 2011). Fazel (2013) assumes the copulative constructions as representations of Persian and provides many examples of which in poetry in order to reveal that Persian employs various copulative clauses in comparison with other Indo-European languages.

None of the linguists in Iran have studied the predicative constructions based on typological point of view. In linguistic typology the world languages' similarities and variations are considered. Different syntactic constructions in languages can be studied according to universalities. Languages may tend to yield one or more than one universality of world languages (the purpose of this article for predicative construction). Comparing the languages for their yielding of universalities, topologists can determine the language type.

\subsection{Non-Iranian Scholars}

Non-Iranian scholars are categorized into two groups in the present study: those who have examined the copulative constructions in Persian, and those who have explored them in English or other languages. The following subsections provide these two analyses. 


\subsubsection{Non-Iranian Scholars’ Analysis Regarding Predicative Construction in Persian}

There are some non- Iranian scholars who have studied Persian predicative constructions. According to them Persian verbs are divided into three categories one of which is "Esnadi" (linking or copular) having no object but a complement defining or describing the subject, e.g.

(1) bæradær-e mænmo?ælem?æst

My brother a teacher is

My brother is a teacher.

(2) hæmkar-æmbimaršod

My colleague ill became

My colleage became ill

Since the words 'teacher' and 'ill' complements the meaning of the verbs, they are called complement. Complements may be either noun or adjective (Mace, 2003). Mace (2003) and Windfuhr (2009) assume the Persian copula as the verb 'to be' in English. The copulas have two forms: the first being the cliticized form, joining the word before the verb and with different representation in different phonetic contexts. The cliticized form in the third singular appears as /Ræst/ (is). The second representation which is called independent or lexical form is /Ræst/, /hæst/, and /baš/ in the present and /bud/ in the past tense. The form /hæst/ may be cliticized as /-Ræm/ instead of /hæstæm/. Sadeghi and Arzhang (1979) assert other uses of /hæst/ for /?æst/ when independent forms are coordinated with conjugation of /budæn/, for example:

(3) vey tævana bud væhæst

He omnipotent was and is

He was and is omnipotent

Or when the agentive clitic pronoun $/-$ Reš $/^{1}$ joins the verb:

(4) ?æhmæddærmænzelhæst-eš

Ahmad in the house is

Ahmad is in the house

The other possibility for appearance of the independent form, according to them, is when the previous word, i.e. 'Mosnad' (predicate) ends in some vowels, for example:

(5) mændanešjuhæstæm

I a student am

I am a student

Lazard (2010[1957]) assumes the verb /hæstæn/ as the independent form of /budæn/, suggesting it can be used as a copula. Additionally, Windfuhr (1979) believes /hæstæn/ to be a substitute for /budæn/ in the present tense and /Ræstæn/ cannot sometimes be used instead of /hæstæn/. Thus, he agrees with Lazard that /hæstæn/ may be used as a copula. The following sentences support the idea: presence of the copula is usually essential in Persian; /hæstæn/ differs from /Ræstæn/ in some cases; and in addition of the copula, /hæstæn/ indicates the meaning of 'to be existent'. Furthermore, the verb /hæstæn/ is the perfective aspect of present tense of the static verb /budæn/. According to Stassen (2005) Persian belongs to the languages with no zero-representation for the copula (Lazard, 2010[1957]; Windfuhr, 1979; Mace, 2003; Stassen, 2005; Stassen, 2009; Windfuhr, 2009).

Among linguists who studied Persian predicative constructions, none of them have dealt with this subject based on typological approach. They have not mentioned the universalities for this construction and any type of language.

\subsubsection{Non-Iranian Scholars' Analysis Regarding Predicative Construction in Other Languages}

Some researchers have studied the predicative construction in languages. Stassen (2005) for example has divided predicates into two categories in all languages: verbal and non-verbal. Non-verbal predicates are of three kinds: nominal, adjectival, and locational. In English all the three non-verbal predicates, each being a simple clause sometimes called copulative, are uniformly encoded by the verb 'to be'. The meaning of these predicates are determined by an NP or AP. Non-verbal predicates differ from non-verbal clauses - with no verb - which is grammatical in English. In English, to be represents the aspect and (passive) voice in addition to being a copula in the non-verbal predicates. This verb represents the VP head with a bleached meaning. The copula in 
copulative and locative/existential constructions is obligatory in English, but absent in such languages as Tagalog. There is a continuum for the overt or covert representation of the copula in the constructions having a predicative $\mathrm{N}$ in languages with no presence in one extreme, and obligatory presence in the other, and in between are languages with no copula under such condition as tense (Stassen, 2005). According to Stassen (2005), the languages with no zero representation of copula are more than the others. In some languages, its representation is in the form of an affix joined to the verbal predicates and sometimes becomes grammaticalized. Some languages grammaticalize other verbs or even such non-verbal elements as pronouns to form the copula. Thus, the copulative construction encoding in different languages may be carried out in different ways (Quirk, 1985; GivÓn, 2001; Kroeger 2005; Drayer, 2007). The use of copula, as mentioned before, is optional in some languages. It can be obligatory in non-verbal predicates (nominal) and optional in non-verbal predicates (adjectival), and vice versa (Drayer, 2007). Being the other kind of non-verbal predicates, locative/existential sentences in some languages including English require the copula similar to one in the nominal and adjectival predicates but it is not the case in other languages (ibid: 238-239). Stassen (2005) suggests two strategies to encode the copulative and locative constructions, namely share and split. Also Stassen (2009) has referred these two universal strategies for encoding predicative constructions in world languages which is the theoretical framework applied to examine the standard Persian in this paper.

\section{Theoretical Framework}

In 2009, Stassen carried out a study regarding the possessive predicates, resulting in the language typology for the construction. Among the findings was the fact that language typology for the various syntactic constructions correlates with other linguistic parameters (Stassen, 2009). Additionally, he had carried out another study in 2005 on the different strategies of languages regarding the encoding of copulative and locative constructions and represented the results in the form of geographical survey maps. Still before that, he had mentioned the topic in a 1997 book regarding the intransitive verbs. However, he assumes among others, the parameter how to encode copulative and locative/existential constructions - sentences having intransitive linking and locative verbs correlated with the possessive predicate constructions. The examples in his book are as followings (p. 265):

(6) John is a tailor.

(7) John is in Paris.

(8) There is music in the air.

Sentence (6) has a copula and (7) has a locative verb. On the other hand, there are some sentences in English like (8) which are among the locative verbs. As is clear, the copula and locative/existential verbs have the same lexical form. Having studied other languages, Stassen found out that all languages do not employ the same lexical form to encode verbs in the copulative and locative/existential constructions. So a single language may use different verbs for any of the sentences. As mentioned before, he suggested two strategies, namely "share" and "split" and introduced a parameter for the relationship between the copulative and locative/existential constructions (Stassen, 1997; Stassen, 2009). Languages select either of the strategies. It is noteworthy that some languages employ both strategies for that. As for languages with the share parameter, the same lexical form is employed, while languages with the split parameter use different verbs for these verbs. English employs a single lexical form, i.e. 'be' for the copulative and locative/existential verbs, so it can be assumed as a share language. Japanese, on the contrary, does not have the same form for the copulative and locative/existential verbs and may be considered as a split one (Stassen, 2009). Yet, Stassen asserts that languages cannot be categorized in terms of being share or split, because as mentioned before, some languages employ both strategies to encode the copulative and locative/existential constructions (ibid).

According to Stassen, either of the parameters has varieties. The first and prevalent class of split parameter is (lexical) "full-split" as seen in Japanese and in which two different verbs are used for the copulative and locative/existential constructions. Another class of split parameter is called "zero-split" in which a lexical verb is employed for the locative/existential construction and a zero copula is used for the copulative construction. Still in another split class a lexical form of verb is employed for the locative/existential constructions and a nominal predicate with a morphologically verb-like behavior is used for the copulative constructions. Languages with the last strategy which may be called "verby-split" are the least (ibid). Another logical possibility regarding the split configuration and encoding is that the copula is a full lexical element and the locative/existential verb is a zero one. But, no language of the kind is practically non-existent for there is a correlation in which if the copula is not zero, then the locative verb cannot be zero. For this reason, this trend is non-existent in languages (Stassen, 2009; Stassen, 1997). 
Stassen suggests the same varieties for the share parameter. The first and the most frequent class employs the same lexical element for the copulative and locative verbs, e.g. in English. It is called (lexical) full-share. The second and the rarest class uses a zero element both for the copulative and locative/existential constructions. This is called "zero-share". Finally, the third class is called "verby-share" in which a nominal predicate having verb features is employed for the copulative and locative/existential constructions. The last two classes are not common among languages (ibid).

Stassen (2005) in another study mentions all the above notions and provides examples for the various strategies from the world languages. He shows in a table that there are two types of languages: split and share, the former is the most frequent. He also points to the various split and share strategies, providing examples from the world languages. He also mounts his findings on the atlases. He believes that language classification in terms of these strategies is not so easy because some languages employ both strategies at the same time, for instance in Tamil from Dravidian languages of southern India, two strategies, namely the copula and zero elements are employed for the copulative clause and a copula is used for the locative one. The reason behind this multiple strategy regards the differences in meaning and any of them is employed for a certain meaning (ibid).

Using the studies by Stassen in 2005 and 2009, the present study is to explore the strategies employed by Persian to encode the copulative and locative/existential constructions and determine its language type with the help of normal data of today Persian extracted from the PLDB.

\section{Data Analysis}

The theoretical framework employed in the present study to explore the encoding of the copulative and locative/existential constructions is a functional-typological one. Since typological studies mostly utilize linguistic corpora, a linguistic corpus is being used in the present study. In this approach, meaning and function are directly related to form. Thus, form and meaning are employed to analyze normal Persian data. At first, some copulative constructions with different forms of / $2 æ s t æ n /$ are provided and the copulas are underlined:

(9) Resm-e mænxodadad?æst

My name Khodadad is

My name is Khodadad.

(10) Rešg-e ?in-ha ?aseman-i?æst

Their love divine is

Their love is divine.

Being copulative constructions, (9)-(10) have the copula as / $2 æ s t /$ with a third singular subject. The above copulas are all the present tense of /budæn/ and an independent form. The 'Mosnads' are NP, AP, AdvP, or PP.

(11) šekæm-et sir-ẹ

Your stomach full is

You are full.

(12) berævimčizibo-xor-im, gorosne-im

Let's go eat something, (we) hungry are

Let's go eat something, we are hungry.

In (11) and (12) the cliticized forms of the copula are used. Subject, 'Mosnad', and the copula are clearly recognized. /bud/ is past tense of the copula /Ræst/, present in (13) and (14).

(13) mohærræmbæray-e bæčče-ha-y-e park mah-e xubibud

Moharam for children in park month good was

Moharam was a good month for children in park.

(14) madær-e bærre-ha zibabud, bæray-e hæminbeh-ešmigoft-ændgozæl

Mother lambs' beautiful was, so her they call Gozal (beautiful in Turkish)

The lambs' mother was beautiful, so they call her Gozal (beautiful in Turkish)

/hæstæn/ is another independent form of the copula /budæn/ and is used as the linking verb in the copulative constructions, instead of the dependent and cliticized forms. The examples (15) - (17) represent the very use of this form of /budæn/. In copulative constructions, whenever emphasized - whether on the 'Mosnad' (Saadeghi 
and Arzhang, 1979) or on the verb (Mace, 2003) - instead of /Ræst/ or cliticized form of the copula, the independent form of /hæst/ is used as in (17). Another condition requiring replacement of / Pæstæn/ by /hæstæn/ is in non-third singular present tense. In (15) and (16) the copula / Ræstæn/ has been conjugated and the lexical form /hæstæn/ is used instead.

(15) mærdom-e `esfehanbæšaš?o karihæstænd

People of Isfihan cheerful and hard-working are

People of Isfihan are cheerful and hard-working.

(16) mærdomikehæmiše?æz?an ja migozærænd, moštæri-ha-y-e xubibæray-e Pin dokan-ha hæstænd

People who always from there pass by, customers good for this shops are

People who always pass by, are good costomers for this shops.

(17) vælinænjundaye-y-e $\mathrm{uu}$ hæmhæst

But Nanjun (grandma in local dialects) his (her) nanny too is

ButNanjun (grandma in local dialects) is his (her) nanny too.

In Persian, different forms of the copula /budæn/ are used to encode the locative constructions. In (18) - (21) /hæst/, /Ræst/, and /bud/ have been used in locative sentences having such prepositions as /ruy-e/ (on), /piš-e/ (with), /bær/ (on top).

(18) kolah-e Baba Ali ruy-e taGče?æst

hat Baba Ali's on the shelf is

Baba Ali's hat is on the shelf.

(19) mæsjed-e fæt'hbæryekbolændi?æst

Mosque Fat'h on an elevation is

The Fat'h mosque is on an elevation.

(20) doxtær-xalehæmpiše an-ha bud

Cousin also with them was

The cousin was also with them.

(21) mæn in-ja hæstæm, in-ja

I here am, here

I am here, here

It is noteworthy that the cliticized copula may be employed in these constructions. For instance (22') is not an ungrammatical version of (22) but rather more informal:

(22) Paramgah-e?u dærmæhælle-y-e toGči?æst

tomb her in district Toghchi is

Her tomb is in Toghchi district.

(22') Paramgah-e?u dærmæhælle-y-e toGči-y-

tomb her in district Toghchi is

In (23) and (24) the copula /hæst/ and /bud/ have been employed to signify 'to be existent'. As was seen in the theoretical framework section, the existential construction is a subcategory under the locative ones.

(23) ?æmma?æknunčændnoktehæst

But now some points there are

But there are some points.

(24) Pin-ja yek?otaG-e bozorgbud

Here a room big there was

There was a big room here. 
It is obvious that the copula can be used to encode the existential sentences, yet the data revealed that the very concept may be encoded by the complex predicate /vojuddaštæn/ in Persian. In addition, the verb /mojud?æst/ was found to signify /vojuddaræd/. The following sentences clearly show the notion:

(25) dær?in xiyabančænddæbirestanvæhonærestan-e herfe-Pivojuddaræd
in this
street
some high schools and
technical schools
there are

There are some high schools and technical schools in this street.

(26) nušidæni-ha-y-e særdmojud?æst

beverages cold there are

There are cold beverages.

As was mentioned before, Stassen in his study (2005) categorizes Persian among the languages with no zero copula. The notion can be verified by omitting the copula in the above sentences and their subsequent ungrammaticality:

(10a) RešG-e Pan-ha Paseman-i?æst

(10b)* ?ešG-e Pan-ha ?aseman-i

Verb omission is also not allowed in the locative and existential constructions. Although some scholars do believe in copula omission under such circumstances mentioned in the review section (Nobahar, 1993; Mahootian, 2008; Vahidian-Kamkar, 2007; Tabibzadeh, 2011).

\section{Conclusion and Discussion}

Having meticulously studied and looked into every aspect of examples and data throughout the corpus, we came up with the following outcomes.

(1) Data analysis revealed that in predicative clauses, copula omission is not allowed in Persian, hence the full or lexical variety of the 'share' and 'split' strategies and no zero copula.

(2) As the normal Persian data suggests, independent and dependent forms of the copula / $æ$ æst/ and its past tense /bud/ are used to encode the copulative constructions in Persian. On the other hand, the conjugated forms of /hæst/ are seen as copula in predicative clauses and copulative constructions.

(3) Additionally, in locative constructions the different forms of the verbs / Ræst/ and /bud/ are used just the same as the cliticized ones.

(4) Being a subcategory of locative constructions, however, existential constructions employ the complex predicates conjugated forms of/vojuddašt/ and /mojud?æst/ as well as the copula.

(5) According to normal data analysis, in today Persian both strategies regarding the encoding the predicative clauses are employed. For on the one hand, the same verb is used in the copulative and locative/existential constructions - the share feature - and on the other hand, the existential constructions have a verb other than the copula - the split feature.

According to the above conclusion we can discuss that in line with Stassen (2009), Persian cannot be categorized exclusively in a share or split type of languages, because it employs both strategies simultaneously and this is the finding of this paper which none of the Iranian linguists refer to.

In this paper the standard Persian has been studied based on Stassen's research in predicative constructions and as author's suggestion, the results and findings of this paper can be examined in other Iranian dialects and languages which can lead to the determination of their language types.

\section{References}

Ahmadi-Givi, H., \& Anvari, H. (2008). Dastoor-e zaban-e Farsi II (Persian Grammar II) (4th ed.). Tehran: Faatemi Publication.

Ash'ari, M. (1994). Amoozesh-e zaban-e Farsi be Farsi (Teaching Persian in Persian). Tehran: Monir publication.

Baateni, M. (1974). Tosif-e sakhteman-e dastoori-ye zaban-e Farsi (A Structural Description of Persian Language). Tehran: Amir Kabir Publication.

Dryer, M. S. (2007). Clause types, Language Typology and Syntactic Description (Volume 1: Clause Structure, 2nd ed., pp. 236-23). Cambridge: Cambridge University Press. http://dx.doi.org/10.1017/CBO9780511 
619427.004

Faazel, N. (2013). Dastoor-e zaban-e Farsi (Persian Language Grammar). Tehran: Agah.

Farshidvard, K. (2005). Dastoor-e mofassal-e emrooz (Today Detailed Grammar). Tehran: Sokhan.

Gernot, L., \& Windfuhr, G. L. (1979). Persian Grammar: History and State of Its Study. Trends in Linguistics, State-of-the-Art Reports 12. The Hague, Paris, New York: Mouton, Pp. ix +303 . International Journal of Middle East Studies, 14(3), 411-412. http://dx.doi.org/10.1017/S0020743800052077

Ghareeb, A., Mlekalshra, B., Forouzanfar, B., Homaei, J., \& Yasami, R. (2006). Dastoor-e zaban-e Farsi (Persian Language Grammar). Tehran: Nahid Publications.

Gholamalizadeh, K. (1995). Sakht-e zaban-e Farsi (Persian Language Structure). Tehran: Ehya.

Givon, T. (2001). Syntax. Amsterdam and Philadelphia: John Benjamin. http://dx.doi.org/10.1075/z.syns

Haakemi, E. (1960). Dastoor-e zaban-e Farsi baraye dabirestanha (Persian Grammar for High School) (Vol. I and II). Tehran: Sherkat-e sahami-ye ketab Publication.

Kroeger, P. R. (2005). Analyzing Grammar an introduction Cambridge. University Press. http://dx.doi.org/10.1017/CBO9780511801679

Lambton, K. S. (1984). Persian Grammar. Cambridge: Cambridge University Press.

Lazard, G. (1957). Grammaire du Persian contemporian. Paris: Autin University of Texas Press (Klincksieck). http://dx.doi.org/10.1017/S0035869X00118350

Lazard, G. (2010). Dastoor-e zaban-e Farsi-ye mo'aser (Contemporary Persian Grammar). Translated by Bahreini, Tehran: Hermes.

Mace, J. (2003). Persian Grammar. Routledge Curzon.

Mahootian, S. (1999). Dastoor-e zaban-e Farsi az didgah-e radeshenasi (Persian Grammar: A Typological perspective). Tehran: Markaz Publication.

Mashkoor, M. (1976). Dastoornameh dar sarf-o nahv-e zaban-e Parsi (A Grammar in Persian Language Morphology and Syntax) (7th ed.). Tehran: Shargh publications.

Meshkaatoddini, M. (1994). Dastoor-e zaban-e Farsi bar paye-ye nazariyye-ye gashtari (Persian Grammar: A Transformational Perspective). Mashad: Ferdowsi University Publications.

Meshkaatoddini, M. (2005). Dastoor-e zaban-e Farsi: vazhegan va peyvandha-ye sakhti (Persian Grammar: Its Lexicon and Structures). Tehran: SAMT Publications.

Mofidi, R. (2011). Budan va dashtan: 2 fe'l-e ista-ye Farsi (To Be and To Have: 2 Static verbs in Persian' Grammar) (pp. 58-89).

Mostafavi, P. (2012). Predicative possession in Persian (Unpublished Ph.D thesis). Department of Linguistics, Allameh Tabatabaei University, Tehran, Iran.

Nobahar, M. (1993). Dastoor-e karbordi-ye zaban-e Farsi (Applied Persian Language Grammar) (1st ed.). Tehran: Rahnama.

Quirk, R., Greenbaum, S., Leech, G., \& Svartvik, J. (1985). A comprehensive Grammar of English Language. London: Longman. http://dx.doi.org/10.2307/415437

Raasekh-Mahand, M. (2009). Goftarhayi dar nahv (Discourses on Syntax). Tehran: Markaz publication.

Ravayee, M. (1991). Dastoor-e zaban-e Farsi (Persian Language Grammar). Tehran: Niloofar.

Saadeghi, A., \& Arzhang, G. (1979). Dastoor-e sal-e sevvom-e ammozesh (Grammar for the 3rd Graders). Tehran: Jalaali Publications.

Shafa'ee, A. (1984). Mabani-ye elmi-ye dastoor-e zaban-e Farsi (The Scientific Basics of Persian Language Grammar) Tehran: Novin publications.

Shari'at, M. (1988). Dastoor-e zaban-e Farsi (Persian Language Grammar) (3rd ed.). Tehran: Asatir.

Stassen, L. (1997). Intransitive predication. Oxford: Oxford University Press. http://dx.doi.org/10.1017/ S0022226799307507

Stassen, L. (2005). Nominal and Locational Predication. In M. Haspelmath, M. S. Drayer, D. Gil, \& B. Comrie (Eds.), The World Atlas of Language Structures. Oxford: Oxford University Press. 
Stassen, L. (2005). Zero Copula for Predicate Nominal, the World Atlas of Language Structures. Edited by M. Haspelmath, M. S. Drayer, D. Gil, \& B. Comrie. Oxford: Oxford University Press.

Stassen, L. (2009). Predicative possession. Oxford: Oxford University Press.

Tabibzadeh, O. (2011). Dastoor-e zaban-e Farsi bar asas-e nazariyye-ye goruh-ha-ye khodgardan dar dastoor-e vabastegi (Persian Grammar Based on Dependency Grammar). Tehran: Markaz publication.

Vahidian-Kamyar, T., \& Omrani, G. (2007). Dastoor-e zaban-e Farsi I (Persian Language Grammar I) (9th ed.). Tehran: SAMT Publications.

Windfuhr, G. L. (2009). Iranian languages. Routledge: London and New York. http://dx.doi.org/10.4324/ 9780203641736

\section{Copyrights}

Copyright for this article is retained by the author(s), with first publication rights granted to the journal.

This is an open-access article distributed under the terms and conditions of the Creative Commons Attribution license (http://creativecommons.org/licenses/by/3.0/). 